\title{
TP53 polymorphism in plasma cell myeloma
}

\author{
Szymon Andrzej Zmorzynski' ${ }^{1}$ Iwona Korszen-Pilecka ${ }^{1}$, Magdalena Wojcierowska-Litwin ${ }^{1}$, \\ Barbara Kwiatkowska-Drabik ${ }^{1}$, Malgorzata Luterek ${ }^{1}$, Sylwia Chocholska ${ }^{2}$, \\ Dorota Koczkodaj', Sylwia Popek ${ }^{1}$, Malgorzata Michalak-Wojnowska ${ }^{1}$, \\ Grazyna Swiderska-Kolacz ${ }^{3}$, Joanna Januszewska ${ }^{4}$, Iwona Surowiec ${ }^{4}$, Waldemar Tomczak ${ }^{2}$, \\ Marek Hus ${ }^{2}$, Anna Dmoszynska ${ }^{5}$, Marcin Pasiarski ${ }^{6}$, Katarzyna Poniewierska-Jasak, \\ Katarzyna Cieplinska ${ }^{6}$, Olga Jankowska-Lecka², Agata Anna Filip ${ }^{1}$
}

${ }^{1}$ Department of Cancer Genetics with Cytogenetic Laboratory, Medical University of Lublin, Poland ${ }^{2}$ Department of Hematooncology and Bone Marrow Transplantation, Medical University of Lublin, Poland ${ }^{3}$ Department of Animal Physiology, Jan Kochanowski University in Kielce, Poland

${ }^{4}$ The Regional Blood Donors Center of Kielce, Poland

${ }^{5}$ Independent Clinical Transplantology Unit, Medical University of Lublin, Poland

${ }^{6}$ Department of Hematology, Holy Cross Cancer Center, Kielce, Poland

\begin{abstract}
Introduction. Significant and accessible predictive factors for bortezomib treatment in plasma cell myeloma $(\mathrm{PCM})$ are still lacking. TP53 codon 72 polymorphism (P72R) results in proline (P) or arginine (R) at 72 amino acid position, which causes synthesis of proteins with distinct functions. The aims of our study were to: 1) analyze whether this polymorphism is associated with an increased risk of PCM;2) study whether the P72R polymorphism affects overall survival (OS) among PCM patients; 3 ) assess the possible association of the P72R polymorphism with sensitivity to bortezomib in cell cultures derived from PCM patients.

Material and methods. Genomic DNA from newly diagnosed 59 patients (without $\mathrm{IgVH}$ gene rearrangements and TP53 deletions) and 50 healthy blood donors were analyzed by RFLP-PCR to identify TP53 polymorphism. Chromosomal aberrations were detected by use of cIg-FISH. The lymphocyte cell cultures from a subgroup of 40 PCM patients were treated with bortezomib (1,2 and $4 \mathrm{nM})$.

Results. The $\mathrm{P}$ allele of the $\mathrm{P} 72 \mathrm{R}$ polymorphism was more common than the $\mathrm{R}$ allele in PMC patients compared to controls (39\% vs. 24\%), and the difference was significant $(\mathrm{p}=0.02)$. The PP and PR genotypes (in combination) were more frequent among cases than in controls $(65 \% v s .42 \%, \mathrm{OR}=2.32, \mathrm{p}=0.04)$. At the cell culture level and $2 \mathrm{nM}$ bortezomib concentration the PP genotype was associated with higher necrosis rates (10.5\%) compared to the PR genotype $(5.7 \%, \mathrm{p}=0.006)$ or the RR genotype $(6.3 \%, \mathrm{p}=0.02)$; however, no effect of genotypes was observed at bortezomib concentrations of 1 and $4 \mathrm{nM}$. The shortest OS (12 months) was observed in patients with the PP genotype compared to patients with the PR or RR genotypes ( 20 months) $(p=0.04)$. Conclusions. The results suggest that P72R polymorphisms may be associated with an increased PCM risk and may affect OS of PCM patients. However, we saw no consistent results of the polymorphism effect on apoptosis and necrosis in cell cultures derived from PCM patients. Further studies are need in this regard. (Folia Histochemica et Cytobiologica 2017, Vol. 55, No. 4, 203-211)
\end{abstract}

Key words: TP53 gene; polymorphism; plasma cell myeloma; bortezomib; apoptosis; necrosis

Correspondence address: Sz. Zmorzyński, M.Sc., Ph.D.

Medical University of Lublin

1 Raclawickie St., 20-059 Lublin, Poland

tel./fax: +48814486100

e-mail: s.zmorzynski@gmail.com 


\section{Introduction}

Plasma cell myeloma (PCM; multiple myeloma) represents $13 \%$ of all hematological malignancies and is characterized by abnormal division of plasma cells $[1$, $2]$. The average age of PCM development is 70 years $[1,2]$. This disease is caused by point mutations and chromosomal aberrations. The latter include translocations, deletions and duplications present in plasma cells. Cytogenetic changes are important prognostic factors in the course of PCM, for example translocations involving IgHV gene locus (14q32) [3, 4]. These translocations include several distinct subtypes, the most common being $\mathrm{t}(11 ; 14)(\mathrm{q} 13 ; \mathrm{q} 32), \mathrm{t}(4 ; 14)$ (p16;q32) and $\mathrm{t}(14 ; 16)(\mathrm{q} 32 ; \mathrm{q} 23)[5]$. Thus the following genes are dysregulated in these translocations: CCDN1 gene (locus at 11q13), FGFR3 and MMSET (locus at 4p16.3), c-MAF (locus at 16q23) [6, 7]. Deletions involving locus (17p13) of TP53 gene detected in newly diagnosed PCM patients are associated with adverse prognosis for progression-free survival (PFS) and overall survival (OS) [8-11]. TP53 gene consists of 11 exons and belongs to the group of tumor suppressor genes. The protein encoded by this gene acts as a transcription factor which regulates expression of genes involved in cell cycle progression and cell growth. Normal TP53 protein inhibits angiogenesis and carcinogenesis [12]. Inactivation of TP53 occurs as a result of mutations or is caused by function of other cellular or viral proteins [13]. TP53 codon 72 (exon 4) polymorphism (rs1042522) is known as a single nucleotide polymorphism (SNP) [14]. This SNP is associated with the presence of nucleotide with $\mathrm{G}$ or $\mathrm{C}$ [14]. Transition of CGC to CCC at codon 72 causes that amino acid $\operatorname{Arg}(\mathrm{R})$ is replaced by Pro $(\mathrm{P})$ in protein structure. The relationship between the presence of SNP in TP53 gene and malignant transformation or clinical response is still poorly understood, especially in PCM. The allele encoding Arg ( $\mathrm{R}$ allele - wild type allele), in comparison to allele encoding Pro ( $\mathrm{P}$ allele), is associated primarily with the induction of apoptosis $[15,16]$. On the other hand, $\mathrm{P}$ allele, in comparison to wild type allele, causes more efficient cell cycle arrest in G1 phase and DNA repair [16, 17]. Arg is localized in the hydrophobic region of the protein which determines the change in its conformation and DNA binding. These features are essential for cell growth suppression [18].

Many researchers have paid attention to the correlation between TP53 codon 72 polymorphism (P72R) and the risk of hematological malignancies [19-24]. $\mathrm{R}$ alleles are associated with an increased risk of solid tumors, such as colorectal cancer, breast cancer and lung cancer [25]. The higher frequency of $\mathrm{P}$ allele is observed in lung and thyroid cancers [26].
Cancer cells are characterized by an increased proliferation and the ability to metastasize. These processes are regulated by the proteasome, which degrades short-lived proteins involved in regulation of cell growth, gene expression, DNA repair, signal transduction and cell cycle progression [27]. The proteasome pathway is a target for a novel cancer therapy [28]. Bortezomib is approved for clinical use in PCM patients and its function as highly selective proteasome inhibitor affects intracellular protein degradation and changes in various signaling pathways within the cell. The inhibition of proteasome causes many effects, for example unfolded proteins response, autophagy, and apoptosis in the case of severe DNA damage $[29,30]$.

Considering the above, we decided to: 1 ) investigate whether the P72R polymorphism confers increased risk of PCM; 2) analyze whether the P72R polymorphism may affect OS of PCM patients; and 3) analyze whether the $\mathrm{P} 72 \mathrm{R}$ polymorphism predicts response to bortezomib in cell cultures derived from PCM patients without $I g V H$ rearrangements and TP53 deletions.

\section{Material and methods}

Patients and bone marrow sampling. For the study, bone marrow aspirates were taken from 59 newly-diagnosed patients with PCM in years 2013-2016, who were hospitalized at the Chair and Department of Hematooncology and Bone Marrow Transplantation, Medical University of Lublin, and Department of Hematology, Holy Cross Cancer Center, Kielce, Poland. The study was conducted after obtaining a positive opinion from the Bioethics Committee (no. KE-0254/165/2013). Abnormalities essential for PCM, such as TP53 gene deletion and $I g H V$ gene rearrangements — $\mathrm{t}(4 ; 14), \mathrm{t}(8 ; 14), \mathrm{t}(11 ; 14), \mathrm{t}(14 ; 16)$, were tested by cIg-FISH according to Ross et al. [31]. The presence of chromosomal aberrations affects the prognosis of PCM. Patients without TP53 gene and $I g V H$ gene mutations were included in the study. This allowed us to obtain homogeneous group, and assess the association of TP53 gene polymorphism with shorter OS. The characteristics of PCM patients are shown in Table 1.

Bone marrow aspirates were divided into two parts. From the first part $(\mathrm{n}=59)$, DNA was isolated and used for determining polymorphism in the TP53 gene. From the second part, cell cultures were established to carry out research associated with cIg-FISH $(n=59)$, as well as necrosis and apoptosis determination $(\mathrm{n}=40)$.

Control samples were made of peripheral blood taken from 50 healthy blood donors at the Regional Blood Donation and Blood Treatment Center in Kielce.

All patients and healthy blood donors have signed an informed consent to provide their samples for this study. 
Table 1. Clinical features of plasma cell myeloma (PCM) patients at the time of diagnosis

\begin{tabular}{|c|c|c|c|c|}
\hline Patients & $\begin{array}{l}\text { All patients } \\
\quad \mathrm{n}=\mathbf{5 9}\end{array}$ & $\begin{array}{c}\text { PP homozygous } \\
n=8\end{array}$ & $\begin{array}{l}\text { Heterozygous } \\
\mathbf{n}=\mathbf{3 0}\end{array}$ & $\begin{array}{c}\text { RR homozygous } \\
n=21\end{array}$ \\
\hline Male/female & $35 / 24$ & $6 / 2$ & $18 / 12$ & $11 / 10$ \\
\hline Mean age (years) & $69.6 \pm 9.62$ & $67 \pm 9.2$ & $71 \pm 9.9$ & $71 \pm 7.9$ \\
\hline \multicolumn{5}{|l|}{ Type of PCM } \\
\hline IgG & 44 & 7 & 23 & 14 \\
\hline IgA & 12 & 1 & 7 & 4 \\
\hline $\operatorname{IgD}$ & 0 & 0 & 0 & 0 \\
\hline $\operatorname{IgM}$ & 1 & 0 & 0 & 1 \\
\hline Light chain & 1 & 0 & 0 & 1 \\
\hline Nonsecretory & 1 & 0 & 0 & 1 \\
\hline Albumins (\%) & $38.9 \pm 8.74$ & $38.45 \pm 7.6$ & $38.76 \pm 8.9$ & $39.52 \pm 8.8$ \\
\hline$\beta 2$-microglobulin $[\mathrm{mg} / \mathrm{L}]$ & $7.5 \pm 3.30$ & $10.58 \pm 3.7$ & $7.48 \pm 2.9$ & $6.37 \pm 2.7$ \\
\hline Calcium $[\mathrm{mM} / \mathrm{L}]$ & $2.41 \pm 0.30$ & $2.47 \pm 0.26$ & $2.49 \pm 0.35$ & $2.29 \pm 0.16$ \\
\hline Hemoglobin [g/dL] & $10.5 \pm 1.70$ & $9.59 \pm 1.8$ & $10.59 \pm 1.6$ & $10.7 \pm 1.6$ \\
\hline \multicolumn{5}{|l|}{ Follow-up* } \\
\hline (Range $0-48$ months) & $30.80 \pm 11.20$ & $21.05 \pm 10.5$ & $34 \pm 11.7$ & $37.1 \pm 10.8$ \\
\hline \multicolumn{5}{|l|}{ Follow-up" ${ }^{\#}$} \\
\hline (Range 4-17 months) & $9.60 \pm 2.38$ & $6.0 \pm 1.1$ & $10.70 \pm 2.90$ & $12.20 \pm 3.40$ \\
\hline Overall survival (Range 1-36 months) & $18.7 \pm 12.8$ & $12.25 \pm 10.8$ & $18.95 \pm 12.3$ & $21 \pm 13.2$ \\
\hline
\end{tabular}

Data are presented as means and standard deviation. *From the moment of PCM diagnosis; ${ }^{*}$ From the end of treatment.

DNA isolation. DNA isolation from bone marrow aspirates $(\mathrm{n}=59)$ and peripheral blood $(\mathrm{n}=50)$ was performed using a commercial kit (Qiagen, Hilden, Germany) according to manufacturer's procedure. The concentration and quality of DNA was checked using NanoDrop device (Thermo Fisher Scientific, Waltham, MA, USA).

TP53 codon 72 polymorphism. The RFLP-PCR (restriction fragment length polymorphism PCR) method was applied for the analysis of SNP. TP53 gene fragment length of 199 bp was amplified by PCR using primers: -forward 5'-TTG CCG TCC CAA GCA ATG GAT GA-3'; -reverse 5'-TCT GGG AAG GGA CAG AAG ATG AC-3'

Each PCR mixture $(25 \mu \mathrm{L})$ contained 150 ng genomic DNA and PCR buffer (Clontech Laboratories, Mountain View, CA, USA), dNTPs mixture $(0.25 \mathrm{mM})$, HD polymerase (Clontech Laboratories) and primers ( $10 \mu \mathrm{M}$ of each). The mixture was heated at $94^{\circ} \mathrm{C}$ for $3 \mathrm{~min}$ and underwent 35 cycles of amplification: denaturation at $94^{\circ} \mathrm{C}$ for $15 \mathrm{~s}$, annealing at $55^{\circ} \mathrm{C}$ for $10 \mathrm{~s}$, elongation at $72^{\circ} \mathrm{C}$ for $30 \mathrm{~s}$. The final elongation took $3 \mathrm{~min}$ at $72^{\circ} \mathrm{C}$. The PCR reaction was performed using 9700 Thermal Cycler (Applied Biosystems, Foster City, CA, USA).

The PCR product was digested with BstUI (Thermo Fisher Scientific, USA) for $16 \mathrm{~h}$ at $37^{\circ} \mathrm{C}$ producing two fragments of 113 and 86 bp or one fragment of $199 \mathrm{bp}$ for presence of $\mathrm{R}$ or $\mathrm{P}$ allele, respectively. RFLP products were analyzed on $3 \%$ agarose gel stained with SimplySafe (Eurx, Gdansk, Poland) and visualized in G:Box (Syngene, Cambridge, UK) (Fig. 1).

Simultaneous staining of cytoplasmic immunoglobulin with FISH (cIg-FISH). Cultured bone marrow malignant plasma cells from 59 patients were identified using simultaneous staining of cytoplasmic immunoglobulin and FISH (cIg-FISH) according to the previously described protocol with modifications [32, 33]. The following probes, all from Abbott Molecular (Abbott Molecular, Abbott Park, IL, USA), were used: Vysis TP53/CEP 17 FISH Probe Kit for detection of del(17p13.1), Vysis IGH/FGFR3 DF FISH Probe Kit for detection of $\mathrm{t}(4 ; 14)(\mathrm{p} 16 ; \mathrm{q} 32)$, Vysis IGH/MYC/CEP8 Tri-Color Dual Fusion FISH Probe Kit for detection of $\mathrm{t}(8 ; 14)(\mathrm{q} 24 ; \mathrm{q} 32)$, Vysis IGH/CCND1 DF FISH Probe Kit for detection of $\mathrm{t}(11 ; 14)(\mathrm{q} 13 ; \mathrm{q} 32)$, and Vysis IGH/MAF DF FISH Probe Kit for detection of $t(14 ; 16)$ (q32;q23). Fluorescent microscopic analysis was performed by scoring 100 AMCA (aminomethylcoumarin acetate)-positive plasma cells to determine the frequency of each aberration. Cut-off levels were $20 \%$ for deletion probes and $10 \%$ for dual fusion probes, according to the recommendations of the European Myeloma Network [31]. 


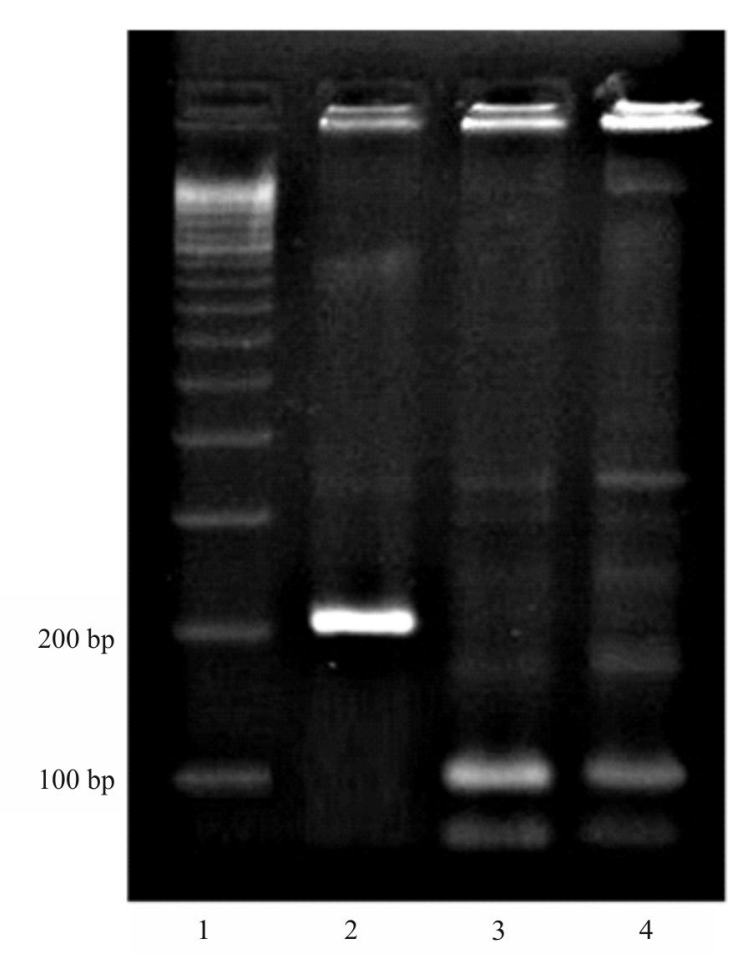

Figure 1. TP53 polymorphism analysis by RFLP-PCR. Line 1 - leader marker (100 bp), line 2- 199 bp band (PP homozygote), lines 3 and $4-86$ bp and 113 bp bands (RR homozygotes). The analysis was performed as described in Material and methods.

Cell cultures, apoptosis and necrosis detection. Bone marrow aspirates $(\mathrm{n}=40)$ (mean number of plasma cells was $34 \% \pm 17 \%$ ) were stratified on Lymphoprep (Axis-Shield, Dundee, UK) and lymphocyte fraction was used to established cell cultures for apoptosis and necrosis detection. The cultures of lymphocyte fraction were grown in $15 \mathrm{~mL}$ of culture medium — RPMI 1640 with L-glutamine (Biomed, Poland); $10 \%$ inactivated fetal calf serum (Biomed, Lublin, Poland), $1 \%$ antibiotic antimycotic (A\&E Scientific, Enghien, Belgium), and different concentrations of bortezomib (LC Laboratories, Woburn, MA, USA, $200 \mathrm{mg} / \mathrm{mL}$ ) - $1 \mathrm{nM}$, $2 \mathrm{nM}$ and $4 \mathrm{nM}$. Bortezomib was dissolved in DMSO and stored at $-80^{\circ} \mathrm{C}$. The final DMSO concentration in culture medium was less than $0.1 \%$. Cell cultures without bortezomib (with $0.1 \%$ DMSO) were used as a control. The volume of $1.0-1.5 \mathrm{~mL}$ of lymphocyte fraction (from each patient) was added respectively to $15 \mathrm{~mL}$ of culture medium. The cultures were grown at $37^{\circ} \mathrm{C}$ in the atmosphere of $5 \% \mathrm{CO}_{2}$ for $24 \mathrm{~h}$. Afterwards the cell cultures were routinely terminated and cell suspensions were prepared to determine apoptosis and necrosis levels by the use of Annexin V-Cy3 Apoptosis Detection Kit according to manufacturer's protocol (Sigma-Aldrich, St. Louis, MO, USA). Viable cells stained green with 6-CF (6-carboxyfluorescein), whereas necrotic cells stained red with AnnCy3 (Annexin V Cy3.18) as analyzed with fluorescent microscope (Nikon Eclipse NiU, Nikon, Tokyo, Japan). Cells starting apoptotic process were stained both with AnnCy3 (red) and 6-CF (green) (Fig. 2). Mainly plasma cells (with diameter 9-12 $\mu \mathrm{m}$ ) were analyzed using fluorescence microscopy according to Carter et al. [34].

Statistical analysis. Values of the analyzed parameters were characterized using frequencies and proportion when measured according to a nominal scale, and characterized using the average and standard deviation and median with the range of variation when measured according to an interval scale. The prevalence of the variant alleles in cases and controls was compared. Odds ratios (ORs) were generated from two-by-two tables and statistical significance was assessed with the Fisher exact test. The Sidak correction test was employed to analyze association of the P72R polymorphism with clinical data, number of apoptotic, necrotic and viable cells. For survival analysis, Cox regression test was used. We assumed a $5 \%$ error of inference and the related level of significance $\mathrm{p}<0.05$ pointing to the existence of statistically significant differences. Statistical analyzes were performed using the IBM SPSS Statistics.

\section{Results}

TP53 codon 72 polymorphism in the studied groups The distribution of the genotypes was consistent with Hardy-Weinberg equilibrium for tested polymorphism. The $\mathrm{P}$ and $\mathrm{R}$ allele frequencies were different in PCM patients than in controls. The $\mathrm{P}$ allele frequency was higher in PCM patients, than in control group (39\% vs. 24\% respectively; $\mathrm{p}=0.02$ ) (Table 2 ). Also, the PP and PR genotypes (in combination) were more frequent among PCM cases than in controls (65\% vs. $42 \%)$ and the difference was significant (OR $=2.32, \mathrm{p}=0.04)$ (Table 3).

Furthermore, the Tp53 genotypes were correlated with clinical data (Table 1 ). The statistically significant differences were observed only at the level of $\beta 2-\mathrm{mi}-$ croglobulin between PP vs. PR $(\mathrm{p}=0.045)$ and PP vs. RR $(\mathrm{p}=0.006)$ genotypes. Also, we analyzed the correlation between P72R polymorphisms and OS of PCM patients. The mean overall survival in patients with the PP genotype was significantly worse than the survival among carriers of the PR or RR genotype (12 vs. 20 months, $\mathrm{p}=0.04$ for difference) (Table 4).

\section{Effects of bortezomib on apoptosis and necrosis in the cell cultures of PCM patients}

Bortezomib increased necrosis and apoptosis in all studied genotypes. The concentration of $12 \mathrm{nM}$ caused death of at least $50 \%$ of cells in all genotypes (PP $-54.4 \%, \mathrm{PR}-51.83 \%$ and RR $-55.25 \%$ ). 

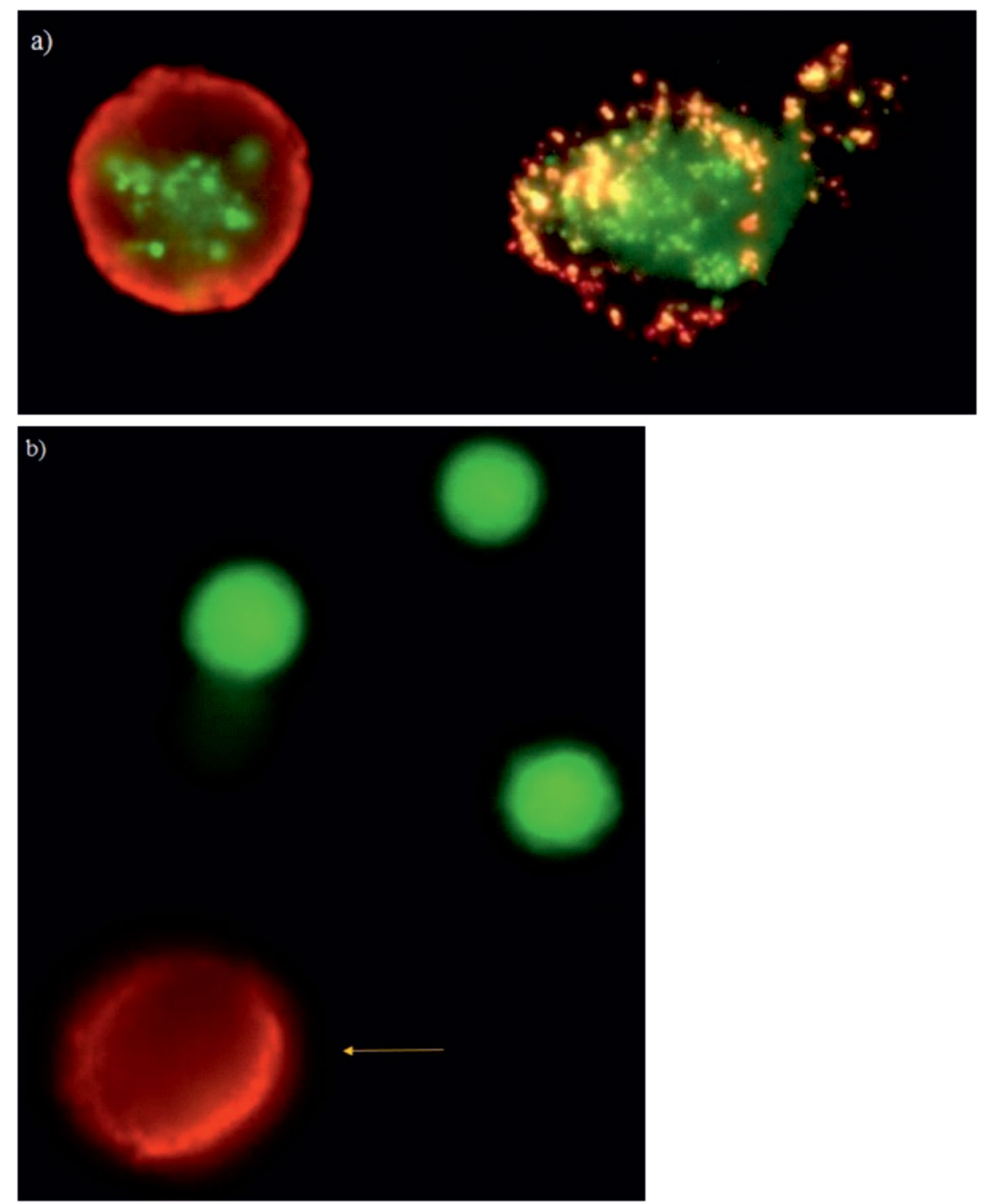

Figure 2. Effects of bortezomib on apoptosis and necrosis of nucleated bone marrow cells. Green — viable cells, red — necrotic cells, yellow-red and green-red - apoptotic cells. A. Apoptotic cells; B. Necrotic cell and lymphocytes (green). For statistical analysis of necrotic/apoptotic/viable cells only plasmocytes with diameter $9-12 \mu \mathrm{m}$ were counted. Cells were stained by immunofluorescent technique as described in Material and methods. Total magnification: 1,500×.

Table 2. The allele frequencies of the P72R polymorphism of TP53 gene in PCM patients and control subjects

\begin{tabular}{|l|c|c|c|}
\hline Allele & Frequency $(\%)$ in study group $(\mathbf{n}=\mathbf{5 9})$ & Frequency $(\%)$ in control group $(\mathbf{n}=\mathbf{5 0})$ & p-value \\
\hline $\mathbf{P}$ & $39 \%$ & $24 \%$ & $\mathrm{p}=0.02$ \\
& $\mathrm{n}=46$ & $\mathrm{n}=24$ & \\
\hline $\mathbf{R}$ & $\begin{array}{c}61 \% \\
\mathrm{n}=72\end{array}$ & $\begin{array}{c}76 \% \\
\mathrm{n}=76\end{array}$ \\
\hline
\end{tabular}

The proportion of necrotic cells increased with bortezomib concentration and reached the highest values at $4 \mathrm{nM}$ for the PP genotype (Table 5, Fig. 2). We observed that the PP genotype at $2 \mathrm{nM}$ of bortezomib was associated with a higher necrosis rates $(10.5 \%)$ compared to PR $(5.71 \%)$ or RR $(6.28 \%)$ genotype, but there was no effect of this drug on necrosis rate at bortezomib concentrations of 1 and $4 \mathrm{nM}$. In the case of necrosis, the statistically significant results were observed at $2 \mathrm{nM}$ bortezomib between the PP vs. PR $(\mathrm{p}=0.006)$ 
Table 3. The distribution of genotypes of the P72R polymorphism of TP53 gene in PCM patients and control subjects

\begin{tabular}{|l|c|c|c|}
\hline Genotype & $\begin{array}{c}\text { Frequency (\%) } \\
\text { in study group } \\
(\mathbf{n}=\mathbf{5 9})\end{array}$ & $\begin{array}{c}\text { Frequency (\%) } \\
\text { in control group } \\
(\mathbf{n}=\mathbf{5 0})\end{array}$ & $\begin{array}{c}\text { OR; 95\% CI; p-value } \\
\text { (PP and PR vs. RR) }\end{array}$ \\
\hline PP & $15.25 \%$ & $6.0 \%$ & OR $=2.32$ \\
$\mathrm{n}=9$ & $\mathrm{n}=3$ & $95 \%$ CI $1.07-5.02$ \\
$\mathrm{yR}$ & $47.46 \%$ & $36.0 \%$ & $\mathrm{p}=0.036$ \\
& $\mathrm{n}=28$ & $\mathrm{n}=18$ & \\
\hline RR & $37.29 \%$ & $58.0 \%$ & $\mathrm{n}=29$ \\
\hline
\end{tabular}

Table 4. Mean overall survival differences between TP53 genotypic groups in PCM patients

\begin{tabular}{|l|c|c|c|c|}
\hline \multirow{2}{*}{ Genotype } & \multicolumn{2}{|c|}{ Mean OS in genotypic groups } & \multirow{2}{*}{ p-value } \\
\cline { 2 - 5 } & PP & PR & RR \\
\hline PP vs. (PR + RR) & 12.25 & 19.80 & - & 0.038 \\
\hline PP vs. PR & 12.25 & 18.95 & 21 & 0.19 \\
\hline PP vs. RR & 12.25 & - & 21 & 0.064 \\
\hline PR vs. RR & - & 18.95 & 0.389 \\
\hline
\end{tabular}

Table 5. The effect of different bortezomib doses on PCM cells apoptosis, viability and necrosis by genotypes of the P72R polymorphism

\begin{tabular}{|c|c|c|c|c|}
\hline \multirow[t]{2}{*}{ Genotypes } & \multicolumn{4}{|c|}{ Bortezomib/DMSO } \\
\hline & $\begin{array}{c}\text { Control (0 nM) } \\
0.1 \% \text { DMSO }\end{array}$ & $1 \mathrm{nM}$ & $2 \mathrm{nM}$ & $4 \mathrm{nM}$ \\
\hline \multicolumn{5}{|c|}{ Necrotic cells $(\%)$} \\
\hline $\mathrm{PP}(\mathrm{n}=16)$ & $1.99 \pm 1.16$ & $5.84 \pm 3.11$ & $10.50^{* * \#} \pm 9.60$ & $12.69 \pm 5.44$ \\
\hline $\mathrm{PR}(\mathrm{n}=19)$ & $3.50 \pm 4.76$ & $5.07 \pm 3.24$ & $5.71 * \pm 1.93$ & $12.13 \pm 6.74$ \\
\hline $\mathrm{RR}(\mathrm{n}=5)$ & $1.99 \pm 1.84$ & $3.86 \pm 2.40$ & $6.28^{\#} \pm 3.17$ & $12.11 \pm 7.13$ \\
\hline \multicolumn{5}{|c|}{ Apoptotic cells (\%) } \\
\hline $\mathrm{PP}(\mathrm{n}=16)$ & $3.56 \pm 2.85$ & $12.27 \pm 7.70$ & $18.25 \pm 3.69$ & $20.03 \pm 6.14$ \\
\hline $\mathrm{PR}(\mathrm{n}=19)$ & $5.35 \pm 3.99$ & $13.44 \pm 7.95$ & $16.82 \pm 4.41$ & $24.69 \pm 10.97$ \\
\hline $\mathrm{RR}(\mathrm{n}=5)$ & $5.23 \pm 5.38$ & $18.12 \pm 15.12$ & $22.57 \pm 12.64$ & $27 \pm 11.61$ \\
\hline \multicolumn{5}{|c|}{ Viable cells (\%) } \\
\hline $\mathrm{PP}(\mathrm{n}=16)$ & $94.20 \pm 5.56$ & $74.90 \pm 12.57$ & $63.46^{*, \#} \pm 15.4$ & $68.28 \pm 7.01$ \\
\hline $\mathrm{PR}(\mathrm{n}=19)$ & $91.11 \pm 6.88$ & $80.21 \pm 10.60$ & $77.34 \pm 8.42$ & $67.52 \pm 12.15$ \\
\hline $\mathrm{RR}(\mathrm{n}=5)$ & $89.31 \pm 8.07$ & $77.78 \pm 13.77$ & $72.86 \pm 13.27$ & $66.36 \pm 12.66$ \\
\hline
\end{tabular}

Data are presented as means and standard deviation. ${ }^{*}, \#$ The differences between PP $v s$. PR and PP $v$ s. RR genotypes, respectively, were statistically significant; ${ }^{*}$ and ${ }^{\#}$ denote $\mathrm{p}<0.01$ and $\mathrm{p}<0.05$, respectively.

and the PP vs. RR ( $\mathrm{p}=0.022)$ genotypes. In a group without bortezomib the highest amount of necrotic cells was observed in the PR heterozygotes (Table 5).

Our study also showed, that bortezomib administration increased apoptosis levels in PCM cell cultures in all genotypes - PP, PR and RR (Table 5, Fig. 2).
The highest apoptosis level was observed in RR homozygotes at 1,2 and $4 \mathrm{nM}$ bortezomib. However, the differences between genotypic groups in the case of apoptosis were not statistically significant.

The statistically significant differences were observed in the number of viable cells after bortezomib 
treatment at $2 \mathrm{nM}$ between PP vs. PR $(\mathrm{p}=0.0004)$ and PP vs. RR $(\mathrm{p}=0.0004)$ genotypes. The highest numbers of viable cells were noted in the PP genotype in control cell and at $4 \mathrm{nM}$ bortezomib, and in PR heterozygotes at $1 \mathrm{nM}$ and $2 \mathrm{nM}$ drug concentrations.

\section{Discussion}

Plasma cell myeloma still remains incurable disease despite considerable therapeutic advances or new drugs like bortezomib. This anti-cancer drug acts as $26 \mathrm{~S}$ proteasome inhibitor. The proteasome enzymes are involved in the degradation of unneeded, damaged or misfolded proteins, which are polyubiquitined by ubiquitin ligases [35]. E3 ubiquitin ligase (MDM2) promotes polyubiquitination of TP53 protein, and then its degradation in the $26 \mathrm{~S}$ proteasome. This mechanism maintains the TP53 gene expression on the normal level [36, 37]. The SNPs at codon 72 of TP53 gene are present in the transactivation domain and may be associated with an increased expression of this gene $[38,39]$. The use of bortezomib prevents the overexpression of MDM2, which causes that TP53 protein is not polyubiquitinated and degraded [40].

The malignant microenvironment plays an important role in the regulation of mechanisms such as apoptosis or necrosis, and in the response to bortezomib [41]. Our research showed that bortezomib increased the number of apoptotic and necrotic cells. The highest apoptosis levels were observed in RR homozygotes. It is known that $\mathrm{R}$ allele encodes Arg 72 protein, which has a much greater ability to induce apoptosis as a result of different location within the mitochondria $[15,16,20]$. Dunna et al. found higher frequency of RR genotype in young patients $(<20$ years) with acute myeloid leukemia (AML) [20]. In our studies lower age of onset in RR homozygotes was observed, but this result was statistically insignificant.

We found the highest amount of necrotic cells in PP genotypes. We observed higher $\mathrm{P}$ allele frequency in PCM patients than in healthy blood donors group, as had been described in the study performed by Ortega et al. [23]. It is known that allele $\mathrm{P}$ activates the transcription of genes involved in the nucleotide excision repair and Pro 72 protein more effectively arrests cell cycle in $\mathrm{G} 1$ phase [17, 42]. This is probably due to altered binding affinity of TP53 protein [42]. We supposed, that higher necrosis levels in PP genotypes are a result of insufficient or disturbed DNA repair mechanisms. When DNA repair is insufficient, the cell should undergo apoptosis. Abnormalities in programmed cell death may cause necrosis [43].

Our studies showed no consistent results concerning the correlation of the P72R polymorphism with the response to bortezomib. We noted statistically significant results only at a dose of $2 \mathrm{nM}$, but this effect was not seen using $1 \mathrm{nM}$ and $4 \mathrm{nM}$ of bortezomib. The effect at $2 \mathrm{nM}$ was weak and of marginal statistical significance. We made many statistical comparisons and some may be by the chance. Further analyses are necessary in this regard.

There are studies which showed correlation between the P72R polymorphism and clinical data. Hattori et al. in the study of PCM patients $(\mathrm{n}=39)$ described shorter progression-free survival (PFS), OS, and post-relapse survival in PP homozygotes in comparison to patients with PR and RR genotypes [21]. Similarly, in our study were observed shortest OS rates in patients with PP genotypes compared to carriers of other genotypes.

There are results which showed that TP53 codon 72 polymorphisms might be related to increased susceptibility to hematological malignancies. For example Liu et al. in patients with chronic myeloid leukemia (CML) found correlation between the PP genotype and increased susceptibility to this disease [22]. Our results showed that carriers of the $\mathrm{P}$ allele (PP or PR genotype) may be at about 2-fold increased risk of PCM. In addition, we observed the highest $\beta 2$-microglobulin levels in carriers of the PP genotype. This protein is a serum marker of PCM development. Patients with high levels of $\beta 2$-microglobulin have an unfavorable prognosis [44]. We did not see any association of the $\mathrm{P} 72 \mathrm{R}$ polymorphism with other clinical factors.

Additionally, TP53 codon 72 polymorphisms may coexist with mutations in various position of this gene. Mutations in TP53 gene are rare ( $\approx 3 \%)$ in newly diagnosed PCM patients [45]. These incidents are higher as the stage of disease advances [45]. TP53 point mutations are often associated with poor prognosis and low survival rate [45]. Chromosomal aberration in the form of $17 \mathrm{p} 13$ (TP53 locus) deletion is a recurrent abnormality in PCM patients, which is associated with less favorable outcome [45-47]. This cytogenetic mutation defined poor prognosis and resistance to chemotherapy of PCM patients [48, 49]. In our study we decided to analyze a smaller but homogeneous study group - patients without TP53 deletion and $\mathrm{IgVH}$ rearrangements (translocations).

In summary, our results showed that the P72R polymorphism may be associated with increased risk of PCM and may affect OS of PCM patients. Bortezomib increased apoptosis and necrosis levels at $2 \mathrm{nM}$, but there was no statistical effect of this drug at concentrations of 1 and $4 \mathrm{nM}$. As the results are not consistent, it is necessary to continue our research in a larger cohort. This will allow precise analysis of ap- 
optotic and necrotic cells in studied TP53 genotypes, and their correlation with clinical parameters.

\section{Conflict of interest}

None declared.

\section{Acknowledgments}

This project was supported by the grants MNmb232 and MNsd233 of the Medical University of Lublin, Lublin, Poland. The equipment used was purchased with funds from 'The equipment of Innovative laboratories doing research on new medicines used in the therapy of civilization and neoplastic diseases' Project, part of the Development of Eastern Poland Operational Program 2007-2013, Priority Axis and Modern Economy, Operations I.3 Innovation Promotion.

\section{References}

1. Palumbo A, Anderson K. Multiple myeloma. N Engl J Med. 2011; 364(11): 1046-1060, doi: 10.1056/NEJMra1011442, indexed in Pubmed: 21410373.

2. Rajkumar S, Dimopoulos M, Palumbo A, et al. International Myeloma Working Group updated criteria for the diagnosis of multiple myeloma. The Lancet Oncology. 2014; 15(12): e538-e548, doi: 10.1016/s1470-2045(14)70442-5.

3. Bergsagel PL, Mateos MV, Gutierrez NC, et al. Improving overall survival and overcoming adverse prognosis in the treatment of cytogenetically high-risk multiple myeloma. Blood. 2013; 121(6): 884-892, doi: 10.1182/blood-2012-05-432203, indexed in Pubmed: 23165477.

4. Rajan AM, Rajkumar SV. Interpretation of cytogenetic results in multiple myeloma for clinical practice. Blood Cancer J. 2015; 5: e365, doi: 10.1038/bcj.2015.92, indexed in Pubmed: 26517360.

5. Kumar SK, Mikhael JR, Buadi FK, et al. Management of newly diagnosed symptomatic multiple myeloma: updated Mayo Stratification of Myeloma and Risk-Adapted Therapy (mSMART) consensus guidelines. Mayo Clin Proc. 2009; 84(12): 1095-1110, doi: 10.4065/mcp.2009.0603, indexed in Pubmed: 19955246.

6. Kuehl WM, Bergsagel PL. Multiple myeloma: evolving genetic events and host interactions. Nat Rev Cancer. 2002; 2(3): 175-187, doi: 10.1038/nrc746, indexed in Pubmed: 11990854.

7. Braggio E, Fonseca R, Fonseca R, et al. Genomic abnormalities in monoclonal gammopathy of undetermined significance. Blood. 2002; 100(4): 1417-1424, indexed in Pubmed: 12149226.

8. Fonseca R, Barlogie B, Bataille R, et al. Genetics and cytogenetics of multiple myeloma: a workshop report. Cancer Res. 2004; 64(4): 1546-1558, indexed in Pubmed: 14989251.

9. Fonseca R, Bergsagel PL, Drach J, et al. International Myeloma Working Group. International Myeloma Working Group molecular classification of multiple myeloma: spotlight review. Leukemia. 2009; 23(12): 2210-2221, doi: 10.1038/ /leu.2009.174, indexed in Pubmed: 19798094.

10. Boyd KD, Ross FM, Chiecchio L, et al. NCRI Haematology Oncology Studies Group. A novel prognostic model in myeloma based on co-segregating adverse FISH lesions and the ISS: analysis of patients treated in the MRC Myeloma IX trial.
Leukemia. 2012; 26(2): 349-355, doi: 10.1038/leu.2011.204, indexed in Pubmed: 21836613.

11. Neben K, Jauch A, Bertsch U, et al. Combining information regarding chromosomal aberrations $\mathrm{t}(4 ; 14)$ and $\operatorname{del}(17 \mathrm{p} 13)$ with the International Staging System classification allows stratification of myeloma patients undergoing autologous stem cell transplantation. Haematologica. 2010; 95(7): 1150-1157, doi: 10.3324/haematol.2009.016436, indexed in Pubmed: 20220069.

12. Kern SE, Kinzler KW, Bruskin A, et al. Identification of p53 as a sequence-specific DNA-binding protein. Science. 1991; 252(5013): 1708-1711, doi: 10.1126/science.2047879, indexed in Pubmed: 2047879.

13. Hollstein M. Somatic point mutations in the p 53 gene of human tumors and cell lines: updated compilation. Nucl Acids Res. 1996; 24(1): 141-146, doi: 10.1093/nar/24.1.141.

14. Kang HJ, Feng Z, Sun Y, et al. Single-nucleotide polymorphisms in the 53 pathway regulate fertility in humans. Proc Natl Acad Sci USA. 2009; 106(24): 9761-9766, doi: 10.1073/ /pnas.0904280106, indexed in Pubmed: 19470478.

15. Frebourg T, Friend SH. The importance of p53 gene alterations in human cancer: is there more than circumstantial evidence? J Natl Cancer Inst. 1993; 85(19): 1554-1557, doi: 10.1093/jnci/85.19.1554, indexed in Pubmed: 8411229.

16. Dumont P, Leu JIJ, Della Pietra AC, et al. The codon 72 polymorphic variants of p53 have markedly different apoptotic potential. Nat Genet. 2003; 33(3): 357-365, doi: 10.1038/ /ng1093, indexed in Pubmed: 12567188.

17. Siddique M, Sabapathy K. Trp53-dependent DNA-repair is affected by the codon 72 polymorphism. Oncogene. 2006; 25(25): 3489-3500, doi: 10.1038/sj.onc.1209405, indexed in Pubmed: 16462765 .

18. Greenblatt MS, Bennett WP, Hollstein M, et al. Mutations in the p53 tumor suppressor gene: clues to cancer etiology and molecular pathogenesis. Cancer Res. 1994; 54(18): 4855-4878, indexed in Pubmed: 8069852.

19. Bilous NI, Abramenko IV, Chumak AA, et al. TP53 codon 72 single nucleotide polymorphism in chronic lymphocytic leukemia. Exp Oncol. 2014; 36(4): 258-261, indexed in Pubmed: 25537220.

20. Dunna NR, Vure S, Sailaja K, et al. TP53 codon 72 polymorphism and risk of acute leukemia. Asian Pac J Cancer Prev. 2012; 13(1): 347-350, doi: 10.7314/apjcp.2012.13.1.349, indexed in Pubmed: 22502699.

21. Hattori Y, Ikeda Y, Suzuki Y, et al. Codon 72 polymorphism of TP53 gene is a novel prognostic marker for therapy in multiple myeloma. Br J Haematol. 2014; 165(5): 728-731, doi: 10.1111/bjh.12784, indexed in Pubmed: 24611901.

22. Liu YC, Hsiao HH, Yang WC, et al. MDM2 promoter polymorphism and p53 codon 72 polymorphism in chronic myeloid leukemia: the association between MDM2 promoter genotype and disease susceptibility, age of onset, and blast-free survival in chronic phase patients receiving imatinib. Mol Carcinog. 2014; 53(12): 951-959, doi: 10.1002/mc.22061, indexed in Pubmed: 23818300.

23. Ortega MM, Honma HN, Zambon L, et al. GSTM1 and codon 72 P53 polymorphism in multiple myeloma. Ann Hematol. 2007; 86(11): 815-819, doi: 10.1007/s00277-007-0347-x, indexed in Pubmed: 17653713.

24. Xiong X, Wang M, Wang L, et al. Risk of MDM2 SNP309 alone or in combination with the p53 codon 72 polymorphism in acute myeloid leukemia. Leuk Res. 2009; 33(11): 1454-1458, doi: 10.1016/j.leukres.2009.04.007, indexed in Pubmed: 19423162. 
25. Papadakis ED, Soulitzis N, Spandidos DA. Association of p53 codon 72 polymorphism with advanced lung cancer: the Arg allele is preferentially retained in tumours arising in Arg/Pro germline heterozygotes. Br J Cancer. 2002; 87(9): 1013-1018, doi: 10.1038/sj.bjc.6600595, indexed in Pubmed: 12434294.

26. Miller DP, Liu G, De Vivo I, et al. Combinations of the variant genotypes of GSTP1, GSTM1, and p53 are associated with an increased lung cancer risk. Cancer Res. 2002; 62(10): 2819-2823, indexed in Pubmed: 12019159.

27. Jung T, Catalgol B, Grune T. The proteasomal system. Mol Aspects Med. 2009; 30(4): 191-196, doi: 10.1016/j. mam.2009.04.001, indexed in Pubmed: 19371762.

28. Rajkumar SV, Richardson PG, Hideshima T, et al. Proteasome inhibition as a novel therapeutic target in human cancer. J Clin Oncol. 2005; 23(3): 630-639, doi: 10.1200/ /JCO.2005.11.030, indexed in Pubmed: 15659509.

29. Jänen SB, Chaachouay H, Richter-Landsberg C. Autophagy is activated by proteasomal inhibition and involved in aggresome clearance in cultured astrocytes. Glia. 2010; 58(14): 1766-1774, doi: 10.1002/glia.21047, indexed in Pubmed: 20645412.

30. Ding WX, Ni HM, Gao W, et al. Linking of autophagy to ubiquitin-proteasome system is important for the regulation of endoplasmic reticulum stress and cell viability. Am J Pathol. 2007; 171(2): 513-524, doi: 10.2353/ajpath.2007.070188, indexed in Pubmed: 17620365.

31. Ross FM, Avet-Loiseau H, Ameye G, et al. European Myeloma Network. Report from the European Myeloma Network on interphase FISH in multiple myeloma and related disorders. Haematologica. 2012; 97(8): 1272-1277, doi: 10.3324/ /haematol.2011.056176, indexed in Pubmed: 22371180.

32. Ahmann GJ, Jalal SM, Juneau AL, et al. A novel three-color, clone-specific fluorescence in situ hybridization procedure for monoclonal gammopathies. Cancer Genet Cytogenet. 1998; 101(1): 7-11, doi: 10.1016/s0165-4608(97)00058-7, indexed in Pubmed: 9460493.

33. Dmoszynska A, Chocholska S. Molecular biology methods in the diagnosis of multiple myeloma. In: Witt M, Dawidowska M, Szczepanski T. ed. Molecular aspects of hematologic malignancies: diagnostic tools and clinical applications. Springer-Verlag, Berlin-Heidelberg 2012: 443-449.

34. Carter A, Hocherman I, Linn S, et al. Prognostic significance of plasma cell morphology in multiple myeloma. Cancer. 1987; 60(5): 1060-1065, doi: 10.1002/1097-0142 (19870901)60:5 < 1060::aid-cncr2820600522>3.0.co;2-3., indexed in Pubmed: 3607725.

35. Monneret $\mathrm{Cl}$, Buisson JP, Magdelenat H. [A new therapy with bortezomib, an oncologic medicinal product of the year 2004]. Ann Pharm Fr. 2005; 63(5): 343-349, doi: 10.1016/ /s0003-4509(05)82301-6, indexed in Pubmed: 16385784.

36. Lane DP, Cheok CF, Lain S. p53-based cancer therapy. Cold Spring Harb Perspect Biol. 2010; 2(9): a001222, doi: 10.1101/ /cshperspect.a001222, indexed in Pubmed: 20463003.

37. Eischen CM, Lozano G. The Mdm network and its regulation of p53 activities: a rheostat of cancer risk. Hum Mutat.
2014; 35(6): 728-737, doi: 10.1002/humu.22524, indexed in Pubmed: 24488925.

38. Gottlieb E, Oren M. p53 facilitates pRb cleavage in IL-3deprived cells: novel pro-apoptotic activity of p53. EMBO J. 1998; 17(13): 3587-3596, doi: 10.1093/emboj/17.13.3587, indexed in Pubmed: 9649429.

39. Wang YC, Lee HS, Chen SK, et al. Prognostic significance of p53 codon 72 polymorphism in lung carcinomas. Eur J Cancer. 1999; 35(2): 226-230, doi: 10.1016/s0959-8049(98)00369-4, indexed in Pubmed: 10448264.

40. Matta H, Chaudhary PM. The proteasome inhibitor bortezomib (PS-341) inhibits growth and induces apoptosis in primary effusion lymphoma cells. Cancer Biol Ther. 2005; 4(1): 77-82, indexed in Pubmed: 15662128.

41. Ercetin AP, Ozcan MA, Aktas S, et al. Ex vivo evaluation of the effect of regulatory $\mathrm{T}$ cells on the anti-tumor activity of bortezomib in multiple myeloma. Exp Hematol. 2016; 44(4): 223-230, doi: 10.1016/j.exphem.2015.05.019, indexed in Pubmed: 26774384.

42. Marin MC, Jost CA, Brooks LA, et al. A common polymorphism acts as an intragenic modifier of mutant $\mathrm{p} 53$ behaviour. Nat Genet. 2000; 25(1): 47-54, doi: 10.1038/75586, indexed in Pubmed: 10802655.

43. Krętowski R, Stypułkowska A, Cechowska-Pasko M. Efficient apoptosis and necrosis induction by proteasome inhibitor: bortezomib in the DLD-1 human colon cancer cell line. Mol Cell Biochem. 2015; 398(1-2): 165-173, doi: 10.1007/s11010014-2216-y, indexed in Pubmed: 25292312.

44. Mihou D, Katodritou E, Zervas K. Multiple myeloma staging based on the combination of beta-2-microglobulin and albumin: the role of albumin in the model. Hematology. 2007; 12(6): 527-531, doi: 10.1080/10245330701384161, indexed in Pubmed: 17852450.

45. Chng WJ, Price-Troska T, Gonzalez-Paz N, et al. Clinical significance of TP53 mutation in myeloma. Leukemia. 2007; 21(3): 582-584, doi: 10.1038/sj.leu.2404524, indexed in Pubmed: 17215851.

46. Lodé L, Eveillard M, Trichet V, et al. Mutations in TP53 are exclusively associated with del(17p) in multiple myeloma. Haematologica. 2010; 95(11): 1973-1976, doi: 10.3324/haematol.2010.023697, indexed in Pubmed: 20634494.

47. Chen MH, Qi CXY, Saha MN, et al. p53 nuclear expression correlates with hemizygous TP53 deletion and predicts an adverse outcome for patients with relapsed/refractory multiple myeloma treated with lenalidomide. Am J Clin Pathol. 2012; 137(2): 208-212, doi: 10.1309/AJCPHC85DGAXZDBE, indexed in Pubmed: 22261445.

48. Chou T. Multiple myeloma: recent progress in diagnosis and treatment. J Clin Exp Hematop. 2012; 52(3): 149-159, doi: 10.3960/jslrt.52.149, indexed in Pubmed: 23269074.

49. Elnenaei MO, Gruszka-Westwood AM, A'Hernt R, et al. Gene abnormalities in multiple myeloma; the relevance of TP53, MDM2, and CDKN2A. Haematologica. 2003; 88(5): 529-537, indexed in Pubmed: 12745272.

Submitted: 24 March, 2017

Accepted after reviews: 18 December, 2017 Available as AoP: 4 January, 2018 